\title{
Article
}

\section{Existentialism and Leadership: A Response to John Lawler with Some Further Thoughts}

\author{
Ashman, Ian \\ Available at http://clok.uclan.ac.uk/13157/ \\ Ashman, Ian (2007) Existentialism and Leadership: A Response to John Lawler \\ with Some Further Thoughts. Leadership, 3 (1). pp. 91-106. ISSN 1742-7150
}

It is advisable to refer to the publisher's version if you intend to cite from the work. http://dx.doi.org/10.1177/1742715007073074

For more information about UCLan's research in this area go to http://www.uclan.ac.uk/researchgroups/ and search for < name of research Group>.

For information about Research generally at UCLan please go to http://www.uclan.ac.uk/research/

All outputs in CLoK are protected by Intellectual Property Rights law, including Copyright law. Copyright, IPR and Moral Rights for the works on this site are retained by the individual authors and/or other copyright owners. Terms and conditions for use of this material are defined in the policies page.

\section{CLoK}

Central Lancashire online Knowledge www.clok.uclan.ac.uk

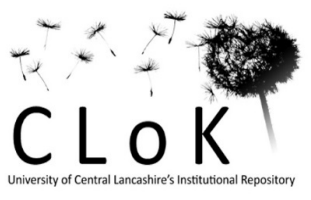




\section{Existentialism and Leadership \\ A Response to John Lawler With Some Further Thoughts}

Word count: 7,470 excluding abstract and references

Author Contact Details:

Dr. Ian Ashman

Department of Strategy and Innovation

University of Central Lancashire

Preston, PR1 2HE

Tel: 01772894782

iashman@uclan.ac.uk 


\title{
Existentialism and Leadership A Response to John Lawler With Some Further Thoughts
}

\begin{abstract}
As the title indicates this article aims to explore and develop some of the issues introduced by John Lawler's recent article for this journal on existentialism and leadership. The intention is to offer further insight into how existentialist ideas and principles can be used to invigorate and reorientate research into leadership. Thus, after an initial re-examination of some of the concepts introduced by Lawler, attention turns to some new themes, including nothingness, Being-for-others and bad faith, before subsequently demonstrating their application to a number of fundamental concerns associated with debates on leadership, such as trait theory, the laissez faire approach and gender.
\end{abstract}

\section{Keywords bad faith; essence; existentialism; followers; gender; Sartre}

John Lawler's article on Existentialism and Leadership in a recent edition of this journal is a welcome contribution to the debates surrounding the conceptualisation and practice of leadership from the point of view of a somewhat neglected philosophy (Lawler 2005). Lawler begins by introducing existentialism, although the article concentrates exclusively on Sartre's version. He proceeds to develop certain themes, in particular, essentialism, meaninglessness, freedom and responsibility and sets out to demonstrate the relevance of each to the study and understanding of leadership. At the end Lawler posits some ‘future questions for leadership’ (2005: 227).

In this response I do not wish to take issue with Lawler's general arguments, rather, as an advocate of existentialism, I hope to clarify one or two assumptions that he appears to make and then offer some further insights that Sartrean existentialism might provide on the subject of leadership. First I want to fill in some more of the historical background to Sartre's version of existentialism by addressing some of the remarks that Lawler makes regarding Sartre and his philosophy. Second, I will seek to clarify 
Sartre's views on essentialism - the theme that seems entirely central to Lawler's arguments - and last, I will introduce three Sartrean concepts that Lawler has chosen to overlook, namely nothingness, Being-for-others and bad faith. Whilst some of the following analysis will be concerned with developing and elucidating certain philosophical matters, the majority, in keeping with Lawler's article, will be focus on reinforcing the relevance of existentialism to the study of leadership.

\section{Sartre the rationalist}

Lawler opens his paper by remarking that:

“The study of management and leadership has a strong rationalist tradition ...” (2005 p215)

He offers existentialism as an alternative perspective to this tradition, which seems to imply that existentialism is somehow a philosophy built upon or sympathetic to irrationality. Existentialism is a widely applied epithet and if we choose to include philosophers such as Kierkegaard, Nietzsche or Unamuno under its rubric then there might be a modicum of truth in that suggestion. However, Sartre's existentialism is entirely rational following in the footsteps of renaissance (Descartes) and enlightenment (Hegel) philosophers as well as the mathematician Husserl's phenomenology. Sartre's pursuit of the understanding of being was an entirely systematic enterprise in many ways conforming to the notion of grand narrative so detested by postmodernists. For instance, in A Sketch for a Theory of the Emotions, Sartre (1996a) makes it quite clear that the head, not the heart, rules consciousness; 
that reason, not emotion drives existence. Iris Murdoch (1999) subtitled her study of Sartre, Romantic Rationalist, for good reason.

What we must be wary of is confusing the recognition of the subjectivity of experience with a shift away from rationalism. There are certain elements of Lawler's reflections on leadership that appear almost solipsistic, a position that Sartre would not have subscribed to. As Lawler points out, there are some (notably Blackham 1961) who view existentialism as nihilistic, based on a dangerous moral indifference, but that was never true of Sartre who no doubt would distinguish a good from a bad leader as quickly as he would distinguish right from wrong (and the two are linked because leadership has an important moral dimension). Many seem to assume that Sartre was a moral relativist, but as his posthumously published Notebooks for an Ethics (Sartre 1983) makes clear he had a strong sense of right and wrong, he simply recognised that people always had choices, the problem being that they could not be depended upon to choose right. Notably, in his discussion on the existence of others in Being and Nothingness Sartre (1996b p223) warns against being marooned on the 'reef of solipsism'. Sartre developed what amounted to an existential phenomenology expressly because he believed that Husserl's transcendental phenomenology veered too close to solipsism. In other words, whilst Husserl supposed that via the method of the epoché the world could be transcended to achieve a pure state of consciousness that would reveal a phenomenon as it really is, Sartre rejected such a possibility, arguing that we are always in-the-world and can never detach ourselves from it. Thus, for Sartre, although the world does have its own objective reality, individuals will continue to interpret that reality in their own different ways because none can transcend it. 


\section{Sartre the existentialist}

Another assertion that needs addressing is Lawler's (2005 p216) contention that Sartre rejected the label of 'existentialist' in his later years as a discussion will help to shed light on some of the issues surrounding Sartre's existentialism. I have been unable to find any evidence of such a rejection, though it is not beyond possibility that Sartre would suggest something that provocative, as he would often think against himself, apart from being deliberately obscure, even disingenuous, to his inquisitors. Nonetheless, it the risk of being a little simplistic, it is still safe to say that Sartre never repudiated existentialism. However, it is true that by around 1960 Sartre had seemingly abandoned most of his existential doctrine and Mary Warnock marked the passing with the following words.

"In 1960 came the publication of Volume I of the Critique de la Raison Dialectique. And in this huge book of 750 pages, Sartre claims to have taken on [the] fundamental task ... of providing a rational foundation for all future thought about man, a foundation for anthropology. He has succeeded in rendering his thought, and the style of his writing, still more abstract and obscure than it was in Being and Nothingness... Indeed it must be admitted that it is a depressing task to analyse this latest book ... for in it we see the spectacle of the death of Sartrean existentialism. (Warnock 1965 p135) 
In his early works Sartre had made it clear that he viewed freedom as absolute and unconditioned. But by the time of the 1946 publication of Anti-Semite and Jew (Sartre 1995) he was qualifying this claim, no doubt as a result of his wartime experiences, by recognising increasingly the force of circumstances and the possibility that certain situations can condition particular responses. Having once argued that there were no innocent victims of war (Sartre 1996b p554), Sartre was now saying, and not surprisingly bearing in mind the facts of the Holocaust, that the plight of the Jews was wholly conditioned by their oppression under the inauthentic attitude of the antiSemite. Gradually, Sartre appeared to be swapping his psychological and philosophical voluntarism for the sociological and economic determinism of Marx.

In retrospect it would appear that Sartre, rather than abandoning existentialism, indulged in what he himself would call inauthenticity. Throughout his life he retained the view that existentialism was the foundation of consciousness (this is borne out in his last interviews with Simone de Beauvoir (1984) in Adieux: A Farewell to Sartre and Benny Levy in Hope Now (Sartre 1996c)), but following the War he chose to suspend that argument because, although existentialism was that rare thing - a philosophical doctrine that could be lived by - it could not present a sympathetic rationale for the Second World War and significantly its individualism offered no mechanism for changing society. Sartre appeared to take to heart Marx's view that philosophers only interpret the world, whereas the point is to change it, so his project until very nearly his end became the uniting of existentialism with Marxism and volume I of the Critique of Dialectical Reason (Sartre 1982a), later published as Search for a Method (Sartre 1968) was his attempt at that reconciliation. 
Unsurprisingly, he failed in this enterprise and returned to his unfinished project of the establishment of an existentialist ethic (Aronson 1996 pp23-34).

\section{Sartre and essentialism}

A particular concern with Lawler's analysis is his discussion of essentialism, which forms the basis for much of his application of existentialism to the study of leadership and so Sartre's position on the matter requires careful explication. The concern for essentialism stems from Sartre's axiom presented in Existentialism and Humanism that 'existence comes before essence' (1966 p26), but to suggest, as Lawler does that Sartre in some way gives pre-eminence to essentialism is mistaken. Lawler qualifies this view by claiming that, with careful reading, it can be seen that Sartre is antagonistic towards essentialism and although Sartre does define 'essence' 'he avoids defining human essence' (Lawler 2005 p218). This seems potentially contradictory and, therefore, requires clarification.

In Being and Nothingness, Sartre (1996b) distinguishes between Being-for-itself, a term that represents a uniquely human form of consciousness that is aware of the possibilities that confront it and the possibility that it can reinvent itself, and Being-initself, which is non-conscious being that nothing more can be said of than that it exists as an object. From the perspective of the for-itself (the prefix Being is often dropped for sake of brevity), the in-itself simply is and as such is predetermined.

"The in-itself is full of itself, and no more total plenitude can be imagined, no more perfect equivalence of content to container. 
There is not the slightest emptiness through which nothingness might slip in.” (Sartre 1996b p74)

For Sartre, in the case of the for-itself, existence precedes essence, however, the initself, is predetermined and absolutely essential. When Lawler cites Sartre as saying 'the essence is not in the object: it is the meaning of the object' Sartre is referring to the in-itself but not the for-itself. Hence, Sartre is making no reference to subjective individual interpretation here as Lawler is suggesting. Rather, it is a rejection of Kant's supposition that objects consist of two aspects; the internal noumena, which is the reality of the object, and the external phenomenon, which is the object's appearance to us. Sartre is adopting the position of Husserl, when arguing in this statement that appearance and reality (objectivity) are irreducible. The statement does not, as Lawler (2005 p219) claims, imply a "unique and individual interpretation given by any individual to his or her own set of circumstances and the meaning they derive from or attribute to it”, but in fact is a reference to the objectivity of phenomenon (Catalano 1980 pp20-25). It is worth remembering that Husserl shared with Descartes the view that philosophy itself must have an 'absolute' foundation, that is, that it should depend upon nothing but itself and in itself be indubitable (Hammond, Howarth and Keat 1991 p16). Thus, Husserl's 'phenomenology is the study of essences’ (Merleau-Ponty 2001 pvii). However, as was earlier noted, Sartre did not wholly concur with Husserl's position and in fact reverted to an almost Kantian dualism that resulted in the separation of the brute existence of the in-itself (what might be called its essence) from our consciousness of it. The distinction is perhaps most clearly illustrated in Sartre’s novel Nausea where Roquentin appreciates the significance of Being-in-itself when contemplating the roots of a chestnut tree in a 
park in Bouville. He realises that existence is not an abstraction, but that it is concrete and particular. It is his constant encounter with existence - the brute reality of other things - that is the source of his nausea (Sartre 1965). To reiterate, what is at issue here is the fundamental difference between Husserl's pure or transcendental phenomenology and Sartre’s existentialist phenomenology. Husserl's phenomenology is entirely essentialist, whereas Sartre acknowledges the essence of the in-itself but rejects the possibility of an essence of the for-itself.

What might be mistaken for an essentialism of the for-itself is Sartre's use of the concept of facticity. Facticity is the term used first by Heidegger to describe any factors in a person's life that they can do nothing about. Accidents of birth are obvious examples, but equally it applies to the consequences of past decisions that cannot be undone, to the parts that other people play in our lives (roles that it may be possible to influence but cannot control) and other factors such as nature and her elements. However, the important point is that, despite the widely held assumption that causality means that the past dictates the present; there is nothing about facticity that makes us, as human beings, behave or feel in any particular way. Facticity does not determine our existence, because there are always gaps of nothingness that present us with choices. To illustrate his argument Sartre chooses, with deliberate irony, the occasion when he was imprisoned.

“Never have we been as free as during the German occupation. [...] The choice that each one of us made was authentic since it was made in the presence of death, since it could always be expressed 
in the form of "Rather death than ...." (Sartre "La republique du silence” Situations, III, pp11-12 cited in Rockmore 1995)

\section{Sartre, meaningless and nothingness}

It is nothingness that is crucial to understanding existentialism as the title of Sartre's 'textbook of existentialism', Being and Nothingness, suggests. Lawler claims that meaninglessness was a prime concern of Sartre's, but the absurd was the principle domain of Camus, whilst Sartre's major interest was nothingness (Sartre never struggled to find meaning, which is why he fell out with Camus over the apparent indifference in the latter’s political treatise The Rebel (Camus 1971)).

The ontological concept of nothingness is fundamental to existentialist thought for a number of reasons. First, it reflects the point of view that human existence rises from nothing and results in nothing (death). Second, nothingness is used to distinguish between extended objects (things) and the metaphysical human consciousness (nothing) and third, as was mentioned when discussing facticity, it is the actuality of nothingness, or we might say the reality of absence, which prevents determinism and enables freedom. Sartre, drawing upon the third premise, explains the concept of nothingness as absence or non-being (1996b p16).

The argument can be understood by considering Sartre's view that:

“Nothingness lies coiled in the heart of being - like a worm.” (1996b p21) 
By this he means that our existence is as concerned with absence as it is with presence. A little later in Being and Nothingness he remarks that:

"Every question in essence posits the possibility of a negative reply. In a question we question a being about its being or its way of being. This way of being or this being is veiled; there always remains the possibility that it may unveil itself as a Nothingness.” (Sartre 1996b p23)

This is a description of negation (denial: the act of saying no). Whenever a question is asked- Can I have it? Does she like me? Are you there? - the answer may be affirmative or negative with neither response having any claim to be of greater significance, or to put it another way, negation is just as important as affirmation to the understanding of any individual's personal circumstance. Of course the question need not be spoken. When a person sits on a chair they are asking the question - will it support me? When they try new food they ask the question - will I like it?

To illustrate the matter Sartre offers the following example.

"I have an appointment with Pierre at four o-clock. I arrive at the café a quarter of an hour late. Pierre is always punctual. Will he have waited for me? I look at the room, the patrons, and I say, 'He is not here.' Is there an intuition of Pierre's absence, or does negation indeed enter in only the judgement? At first sight it seems absurd to speak here of intuition since to be exact there could not 
be an intuition of nothing and since the absence of Pierre is this nothing. Popular consciousness, however, bears witness to this intuition. Do we not say, for example, 'I suddenly saw that he was not there’?” (1996b p9)

So, despite the fact that the busy, noisy, smoky café is a 'fullness of being' what is critical to Sartre is the nothingness that is Pierre's absence - reality has revealed an absence, a nothingness to Sartre’s question - is Pierre here?

Sartre's point is that in nothingness rests a multitude of realisable possibilities, though they are to some extent delimited by our expectations. It is non-being that reveals possibility and reveals the discontinuities in causality. Nothingness represents the gaps that allow one to act on those possibilities. This is the root of Sartre's antiessentialism of being-for-itself, although anti-determinism might be a more accurate expression than anti-essentialism.

The concept of nothingness will be applied to thinking on leadership in due course, but for now it is important to return to Lawler's remarks on essentialism, in particular to his mistaken claim that there can be no 'essence' of leadership. The antiessentialism of existentialism only extends so far as being-for-itself (that is, human beings) whereas being-in-itself is entirely essential, absolutely determined. The essentialism of being-in-itself can certainly be extended to abstract concepts such as leadership. It is perfectly reasonable to argue, if perhaps impossible to prove, that the essence of good leadership is intellectual rigour, moral fortitude and social skill. What cannot be claimed is that an individual in developing such capacities will inevitably 
become a good leader. Hence, from an existentialist perspective, as Lawler is correct to say, leaders are not determined by their heredity or even their upbringing, but derive from their situation and the choices they make. However, he is incorrect to assert that there can be no essence of leadership.

Thus far, in response to Lawler's discussion, I hope to have demonstrated that Sartre's philosophy is entirely rational, that he did not reject his early existentialist doctrine, that his anti-essentialism (antideterminism) extended only so far as being-for-itself (human beings) and that nothingness is a more fundamental (and, therefore, perhaps more useful) concept in Sartre's philosophy than meaninglessness. The intention is now to take some of these points along with other Sartrean ideas and further apply them to the study and understanding of leadership.

\section{Existentialism, nothingness and leadership}

To begin with it is necessary to concentrate on the concept of nothingness. I have argued here and elsewhere (author name removed 2006) that nothingness, that is, the absence of being, lies at the heart of Sartrean existentialist thought. It is notable that whenever leadership (or any other subject of organizational psychology/HRM) is discussed concern is reserved almost exclusively for what is present - who is involved what they are doing and so on. Researchers pay very little, if any, attention to who or what is absent. This is hardly surprising bearing in mind the empiricist tradition in organizational psychology (and the social sciences more generally) which precludes the study of absence, and yet the respondents or actors involved in field research concern themselves with absence all of the time. Myerson (2000 p75) suggests we: 
"Think of all the commonplace phrases that involve the word 'nothing' [...] It seems that we are continually relating our lives to 'nothing'. The word 'nothing' slips endlessly into our everyday lives.”

For instance, if Peter is leading a project team the individual team member's consciousness of Peter is as likely to be influenced by what is absent as by Peter's presence - they might say 'he's nothing like Carol, if she were here leading this project things would be much better'. If a team member were to say that Simon is too intolerant to be a good leader what they are arguing is that the absence of tolerance mitigates Peter's ability to lead as much as the attributes that he does possess. However, so much is absent that the significance of what is missing will very much depend on individual expectations and that has clear implications for the methods by which leadership can be studied. Undoubtedly, there needs to be a shift away from the popular cross-sectional survey approach (Yukl 2002 p435) towards a longitudinal ethnographic methodology that invokes the spirit of existential psychoanalysis (there is not space here to introduce this method, but interested readers should refer to (Sartre 1996b pp557-574) or the work of Laing (e.g. 1990)).

There is a danger though, that this type of comparative analysis promotes a form of the trait theory of leadership. However, it should not be viewed in this way because, as Lawler is at pains to point out, no existentialist would subscribe to such a theory, as they would inevitably reject the implied determinism of what is often referred to as the 'great man/great woman' hypothesis (Shackleton 1995 p7). That is not to say that 
traits are not important in leadership, but crucially it should be recognised that any trait is mediated by existential choices. An individual's traits and their application result from the free will of that individual and in turn those traits are greatly influenced by the freely selected values and beliefs of that individual. In his short story The Childhood of a Leader Sartre (1975) sets out to illustrate how a fascist is created through his own choices, not by dint of heredity, circumstances or conditioning. His central character, Lucien Fleurier, has numerous encounters with his family, with homosexuality and with Jews that might be seen as the cause of his joining the fascist organization L'Action Francaise. Indeed, Lucien wishes to blame these events for his passage to fascism, but Sartre insists that we see the events as occurrences punctuated by spaces where the freedom lay to adopt an alternative course. Lucien becomes the leader of a fascist group, not because of destiny, but because he chooses to (Thody 1992 pp75-84).

There is a further reason for questioning trait theories of leadership from an existentialist perspective, which is because trait theory sets out to establish an abstract rendition of the characteristics of leadership and then present them as universally applicable. This abstract universalism is quite at odds with the pre-eminence of the concrete and particular in existentialist thought. Such a position may appear to contradict the earlier assertion that it is meaningful to talk of the essence of leadership. That assertion remains as correct - it is meaningful - however, from an existentialist standpoint it is of little value because we are fundamentally in-the-world where each and every situation is unique. Abstract theory has its place as a springboard for action, but it cannot determine our actions because we always find ourselves situated and having to make choices. Of course, situational leadership 
theory, although sounding more promising, is equally abstract, because the situations in question are not treated as unique but as categories of events to be diagnosed and treated in a formulaic manner.

Whilst undoubtedly provoking interest it is apparent that the existentialist position creates problems for the research community. Having a moment ago suggested that certain approaches to research are preferable to others it has to be acknowledged that there is a danger that if every leadership act is situated, concrete and particular then there is no hope of generalization, which is the impetus and justification for most investigations in the field. Of course, that is a somewhat narrow view of the purpose of research, but where resources are scarce it is difficult to sell a research project on the premise that any lessons learned about leadership, although potentially insightful, are not easily transferable (if at all).

These issues will be addressed later when gender and leadership is discussed, but for now, leaving aside the practicality of existentialist research, it is salient to identify another leadership debate where the notion of absence is fundamentally important. The laissez-faire style leadership:

"Describes a leader who is not actively involved in followers' work. The leader avoids taking a stand on issues, refrains from intervening, lets others do as they please and is absent, disorganized and indifferent.” (Shackleton 1995 p114) 
It is a strange conceptualisation of leadership because it is not leadership at all and many of the more creditable texts in the discipline do not refer to it perhaps for that very reason. However, from an existentialist perspective it represents an area of interest, even if laissez-faire leadership is a misnomer, because it asks questions as to what happens in the absence of leadership. The assumption is that the absence of leadership is always a bad thing representing inadequacy and failure, perhaps reflecting the original research of Lewin, Lippit and White (1939) where laissez-faire was invented as a category of leadership style that contrasted with the desirability of a democratic approach to leadership, resulting in task inefficiency and apathetic followers (Gastil 1994, Carey 1977). There is no consideration of the choices made by a nominated leader to absent themselves from the role or the possibility that 'followers' could function effectively without formalised leadership.

\section{Leaders, followers and Being-for-others}

It is implicit in much of the literature that leadership is an inherently desirable responsibility to attain and that leadership is in effect something that is done to other people. It would be an exaggeration to say that the part played by followers in the analysis of leadership is ignored, but they are paid relatively scant attention, which is surprising when considering that they outnumber the leaders and it is generally by their actions that leaders are judged. The assumption seems to be that leadership is something to be aspired to (McClelland 1961) and that given a favourable personality and a conducive situation then subordinates act simply as objects (Being-in-itself) to be manipulated like so much machinery. However, if leaders choose to lead, then followers must choose to follow and there is nothing straightforward about those 
choices; a fact that is thrown into sharp relief through an existentialist evaluation that, in particular, draws upon Sartre's concepts of Being-for-others and 'the look'.

Thus far, two categories of existence have been established; Being-in-itself and Being-for-itself, however there is a third category, Being-for-others. It is Sartre's contention that humans see other people as Being-in-itself, but other consciousnesses have a particular affect upon us that non-human objects do not. Whilst the existentialist rejects determinism he or she also acknowledges that the freedom of any individual is in some way dependent upon the freedom and actions of all other individuals. Thus, the for-itself, becomes aware that it is also for-others - the discovery that not only do we objectify others, but other people objectify us also. Being-for-others fundamentally alters the experience of our self as Being-for-itself because it affects our emotional state.

In a part of Being and Nothingness called 'The Look' Sartre (1996b pp252-302) explains that when a person gazes upon another person they do indeed objectify them, in the same way that they objectify a tree or a stone. Yet, immediately they are aware that the other also 'looks', or at least has the potential to 'look' back at them and so objectify them also ${ }^{i}$. The other, therefore, destabilises an individual's freedom by competing for it. Sartre, somewhat dramatically, refers to an internal haemorrhaging as one's world drains into the world of the other. In a more mundane way Sartre illustrates the principle by asking how we feel when we see someone in the park. At first, he says, all the objects in the park (trees, benches and so on) are understood spatially in relation to us. However, when we notice another person the relationship 
shifts suddenly as objects group themselves spatially around that person. Sartre suggests that it is as if our world has been stolen from us.

The significance of 'the look' becomes more apparent when considering it in connection with particular emotions that, Sartre argues, can occur only in the real or imagined presence of others, such as shame, fear, pride, arrogance or modesty. What is perhaps difficult to grasp regarding this conceptualisation is that we seem to be apprehending the other as both object and subject.

The way in which Sartre illustrates this in Being and Nothingness is with the following example.

"I have just made an awkward or vulgar gesture. This gesture clings to me; I neither judge it nor blame it. I simply live it. I realize it in the mode of for-itself. But now suddenly I raise my head. Somebody was there and has seen me. Suddenly I realize the vulgarity of my gesture, and I am ashamed. It is certain that my shame is not reflective, for the presence of another in my consciousness, even as a catalyst, is incompatible with the reflective attitude; in the field of my reflection I can never meet with anything but the consciousness which is mine. But the Other is the indispensable mediator between myself and me. I am ashamed of myself as I appear to the Other.” (1996b p221-2) 
So, consciousness is a complex foundation comprising of an awareness of the foritself and for-others in relation to the in-itself and the result of that consciousness is what existentialists refer to as angst. Angst is a condition that draws from the generality of existence. Its sources are uncertainty, freedom, possibility, responsibility and, if Sartre is to be believed, 'other people'.

Sartre's argument is presented in Being and Nothingness but it is perhaps best illustrated with reference to his most well-known play Huis Clos (variously translated as In Camera or No Exit), written in 1944, and from which the claim is made that:

“Hell is ... other people.” (Sartre 1982b p232)

Huis Clos is an unusual depiction of hell - one that amounts to three people coexisting in a drawing room for all eternity. The three characters are Garcin, a coward, Inez, a lesbian who murdered her lover, and Estelle, also a murderer. Initially, they are surprised that there are no 'hellish’ instruments of torture to be found - no fire and brimstone, no burning marl, no red hot pokers - but soon they come to realise that they are each the unwitting torturer of the other two. Each is trying to force the others into seeing them in the way they would like to be seen and the result is a clash of egotistical self-visions which are in permanent conflict (Thody and Read 2003 p63). The play, therefore, reflects the view, one that can also be found in the work of Hegel, that other people are a source of great angst because they see individuals as they are (a coward or selfish murderer) rather than how they wish to be seen (a hero let down unfortunately by his body or a misunderstood victim of circumstances, in the cases of Garcin and Estelle). In other words, whilst we may wish to be judged on what we 
think or feel, we will inevitably be judged on our actions. However, the fact that there are three characters is significant, because Sartre believes that when a relationship is between just two people they may succeed in being complicit in a mutual deceit. For instance, Garcin and Estelle are on the brink of indulging each other's self-deception but they can never achieve their goal because Inez must always collapse the artifice. It is not difficult to appreciate how leadership, as a very public activity, involves a potentially angst ridden dynamic involving leader and followers.

Recasting the dynamic of leadership and following in this way has the potential to energise ideas that are not new but that receive little attention in academic literature, for instance, leading by example. The existentialist foundations of Being-in-the-world and commitment as a call to action (Sartre 1966) predicate deeds over words; action above rhetoric. The recent debate in the UK regarding the 'fat cat' pay of corporate executives would undoubtedly benefit from an evaluation through the lens of existentialism. Leadership in general, and moral leadership in particular, has currently a high political, social and economic profile and existentialism offers a great deal of food for thought regarding the motives of leaders and their influence on followers

\section{Leadership and bad faith}

It is a surprise perhaps, bearing in mind Lawler's reliance on Sartre's account of existentialism, that he overlooks one of Sartre's most enduring concepts - bad faith. Existentialism, in general, and Sartre's version in particular, is concerned fundamentally with human choice. It is the ability to choose that distinguishes the foritself from the in-itself and that imbues humankind with freedom. If the human 
condition revolves around the making of choices and the processes by which those choices are made then they must be central to the analysis of leadership.

We are familiar with the refrain from Shakespeare's Twelfth Night that "some are born great, some achieve greatness and some have greatness thrust upon 'em”, so can the same be assumed of leadership? Many would say so. However, according to existentialist doctrine the journey to any situation must involve personal existential choice. So, to become a leader, or a follower, involves making choices. Even appearing not to choose, to cede to the situation, involves a form of choice. The issue is that we often feel we have no choice or that we do not want to have to choose. In fact, it is only quite rarely that we feel we are creating our destiny through our own decisions. Sartre introduces two concepts to explain this feeling.

The first concept, facticity, was discussed earlier. The second, bad faith (in French mauvaise foi), stems from the desire to avoid having to make choices (Sartre 1996b pp47-70). As conscious agents we are continually confronted by choices and whilst many are so trivial they hardly warrant our attention a significant number are not. Frequently the act of being forced to choose is a far from pleasant experience, resulting in what existentialists refer to as angst, anguish or anxiety. Sartre describes the sensation as a 'vertigo of possibility'. For instance, a leader who is forced to favour one or other of two equally deserving acolytes will almost certainly experience a sense of discomfort in making a decision. Likewise, the impending consequence of deciding between two or more different courses of action is inevitably imbued with a sense of foreboding. In many situations we would rather not have to choose and so we often pretend that we really have no choice, which is what Sartre means by bad faith. 
The term bad faith sounds negative, but it should not viewed in this way, as acting in bad faith is a quite natural ruse that we employ to avoid experiencing angst. Bad faith is an inauthentic attitude, because from the perspective of the existentialist we can never claim genuinely that 'we were made to do something' or that 'we had no choice'. In this respect existentialism is an extraordinarily harsh philosophy because it contends that anyone beyond l'age de raison with their physical and mental faculties intact always has at least two options - life or death. However, for the most part we are quite unaware that we may be acting in bad faith and it is only upon careful reflection that such an attitude comes to light. Some, for example Fingarette (2000) liken bad faith to self-deception, but it is considerably more complex than that and Sartre has argued that it is quite impossible for an individual consciousness to deceive itself:

"If I deliberately and cynically attempt to lie to myself, I fail completely in this undertaking; the lie falls back and collapses beneath my look; it is ruined from behind by the very consciousness of lying to myself which pitilessly constitutes itself well within my project as its very condition.” (Sartre 1996b pp49-50)

When acting in bad faith the individual is quite convinced that the choices that do exist, do not.

Perhaps the most frequent activity undertaken by leaders is decision making. It could be argued that the application of the concepts of facticity and bad faith would 
enlighten any analysis of the decision making process. As an illustration we might consider the ongoing debates surrounding gender and leadership.

\section{Leadership, gender and existentialism}

The issue of whether male or female characteristics are best suited to leadership roles seems ripe for analysis from a less orthodox perspective. Of course, from an existentialist point of view the debate is erroneous as it is mistaken to consider any characteristic as essentially male or essentially female. Simone de Beauvoir is famous for her assertion from The Second Sex that "one is not born, but rather, becomes a woman” (de Beauvoir, 1997:295), by which she means that women often possess stereotypically female characteristics not because they are genetically encoded, nor through their own existential choice, but as a result of social pressure. The unavoidable conclusion is that women frequently adopt 'female' characteristics in bad faith, however, it must be reiterated that such a consequence is a quite authentic attitude to adopt when confronted with the circumstances of a masculine society.

The purpose of an existentialist analysis of gender and leadership would not be to contest current feminist thinking but to explore the evidence available with a different emphasis. Existentialism places prominance on individual choice and locates ultimate control of the decision making process in the hands of the individual. One cannot escape the fact that "most managers in most organizations in most countries are men" (Collinson \& Hearn 1996 p1), but research into why this is the case has concentrated largely on the social superstructures and cultural mores that maintain the situation, rather than the choices made by women faced with leadership opportunities or who 
have ambitions to lead. For instance Hojgaard (2002) traces differentiation in gendered leadership through a constructivist approach and she draws numerous conclusions regarding structural factors influencing (perhaps, she might argue, determining) the make up of gender and leadership in three sectors of Denmark's economy. Her analysis reinforces orthodox views on the subject but offers limited insight. Tellingly, she remarks:

"the interesting question is how to account for the differences in gender negotiating space between sectors. This analysis cannot tell us to what extent sector-specific negotiating spaces are a result of inner dynamics or cultural specificities within the sector or between the sector and the social context in which it is embedded.” (Hojgaard 2002 p35)

An existentialist study (which of course would require a very different research approach from the survey method used by Hojgaard) would help to answer that question. Negotiation, being a process of taking a position, making choices, and then shifting position, can be subjected to existential analysis if one looks beyond the process and explores the conscience of the negotiator - in particular, their perception of the positions and choices available to them, the extent to which they are acting in good or bad faith. The intention is never to be critical of the individual but to better understand their sense of situation and reestablish their sense of control.

Marshall's (1995) study, Women Managers Moving On, offers a research approach much better suited to an existentialist analysis than Hojgaards. However, despite subtitling her book Exploring Career and Life Choices there is little exploration into 
the choices made by the sixteen women contributing to the study - at least not in an existentialist sense. In particular, there is no discussion of the options open to the research subjects, their own understanding of their decision making processes or their reasons for rejecting (neglecting or even denying) various possibilities.

There is a sense that the choices made by the women are to be taken as a given, both to them and the reader, once the circumstances have been established. Such assumptions mask rather than reveal the relationship between gender and leadership or management. There are a number of instances where bad faith seems to play a part in choices made. For instance, in her testimony, Mercedes, a deputy director in local government, describes “a typical way a woman behaves”:

"Women wait until they can do the job and then they apply, whereas blokes apply all the time, whether they can or can't do the job, have a good interview and they get the job. And women prop them up.” (Marshall 1995 p201)

The remark passes without commentary, but it deserves exploration. Here we see gender essentialised in a way that appears to determine Mercedes' attitude towards her career. Such essentialising is evidence of bad faith, but that in itself is not important. The real issue is how bad faith acts to influence and constrain her decisions and choices as she strives to achieve the position, which she eventually attains in a different organization. Mercedes claims that some of the women she had encountered on selection panels were biased against other women (Marshall 1995 p201). She does not consider herself a feminist but is committed to empowering 
women, so what would be interesting to know, from an existentialist perspective, is how that commitment is translated into action and if there is any evidence of bad faith. It is reasonable to assume that women who reach positions of leadership will influence the women beneath them in the organizational hierarchy (Burke \& McKeen 1996, Ely 1991) so the adoption of stereotypically male characteristics to get to and retain positions of power could be counter productive.

The notion that for a woman to be an effective leader she has to jettison her sexual identity is discussed by de Beauvoir (1997 p161) who points out that:

“Queen Isabella, Queen Elizabeth and Catherine the Great were neither male nor female - they were sovereigns.”

The inference being that whilst a woman can be a leader society will no longer accept her as a woman (nor can she be a man) so she is simply a leader. Of course, the same logic does not apply to men as being masculine and a leader is quite compatible. However, denying one's sexual identity involves bad faith and what is at issue here should not be - which characteristics, masculine or feminine, are perceived to be the most effective (see, for instance, Powell, Butterfield \& Parent 2002) - but, to what extent are leaders, female or male, adopting the characteristics of a cultural ideal because, in bad faith, they feel they have no alternative and so are perhaps doing aspiring women a disservice?

For instance, Marshall (1995 p211) describes Stevie as a young woman who acted as a pioneer for women in her chemicals company despite her success ensuing from a 
strategy she referred to as "being a female man”. Similarly, another subject called Teresa dealt with the hostility of senior managers in a male-dominated environment by “becoming more tough and aggressive herself” (Marshall 1995 p123) to the point where she began to dislike herself for adopting such a persona (p133). There is clear evidence of bad faith on the parts of both Stevie and Teresa even though they provide quite reasonable rationales for their behaviour and in the end they left their respective organizations, perhaps to pursue a more authentic path. The problem is that Marshall does not explore these matters, which leaves a considerable gap in the analysis. Arguably, an existentialist approach would enable a constructive analysis of the way of thinking (as opposed to simply the circumstances) of such women and perhaps shed light on why, despite seeing their numbers increase in middle management, women are unable to secure executive positions in organizations (Oakley 2000).

Perhaps, to some extent, women have been complicit in the maintenance of a male oriented society. De Beauvoir (1997 pp93-97) provides three reasons for male preeminence through history. First, women carry the burden of reproduction making them dependent upon men across significant parts of their lives. Second, the domesticity that accompanies reproduction (childbirth and child rearing) imprisons women in repetitive activity and in a single location. And third, society elevates the male predilections for taking and risking life above the female’s giving of life.

The third reason can only occur because women operate as active accomplices in ensuring the continued pervasiveness of masculine society (Mahon 1997 p125). According to de Beauvoir (1997 p96) this is because: 
"[woman], too, is an existent, she feels the urge to surpass, and her project is not mere repetition but transcendence towards a different future - in her heart of hearts she confirmation of the masculine pretensions. She joins the men in the festivals that celebrate the successes and victories of males.”

So, women harbour the same ambitions as men, but they are not men, nor should they desire to be male, for that is bad faith. Whilst science and technology have negated the first two reasons to a considerable extent, perhaps the third reason is still sublimated in the leadership hierarchies of twenty-first century organizations.

\section{Conclusion}

Following from John Lawler's article I hope to have reinforced the idea that existentialism is a philosophical viewpoint that has a great deal to offer the study of leadership. I mentioned in passing that existentialism is a philosophy to live by and I have attempted to demonstrate that Sartre's concepts, despite their complexity, are applicable directly to issues at the forefront of contemporary debates surrounding leadership. Existentialism is concerned with what I have described as the concrete and particular, with being-in-the-world. In other words it focuses attention on the dayto-day, situated, experiences of subjects, rather than on the abstract generalisation common to a great deal of leadership research. There are clear ramifications for approaches to leadership research in the future, but space limitation does not permit their explication here. 


\section{References}

Aronson, R. (1996) 'Sartre's Last Words' an introduction to J-P. Sartre Hope Now:

The 1980 Interviews, translated by Adrian van den Hoven, Chicago, University of Chicago Press,

Author name removed (2006) 'Business Ethics and Existentialism’ Business Ethics: A European Review, issue to be confirmed.

Blackham, H.J. (1961) Six Existentialist Thinkers, London, Routledge and Kegan Paul.

Burke, R.J. \& McKeen, C.A. (1996) 'Do Women at the Top Make a Difference? Gender Proportions and the Experience of Managerial and Professional Women', 49(8), 1093-1104.

Camus, A. (1971) The Rebel, translated by Anthony Bower, Harmondsworth, Penguin.

Carey, A. (1977) 'The Lysenko Syndrome in Western social Science', Australian Psychologist, 12(1), 27-38.

Catalano, J.S. (1980) A Commentary on Jean-Paul Sartre’s Being and Nothingness, Chicago, University of Chicago Press. 
Collinson, D. \& Hearn, J. (1996) 'Breaking the silence: On Men, Masculinities and Management' in D. Collinson \& J. Hearn (eds) Men as Managers, Managers as Men: Critical Perspectives on Men, Masculinities and Management, London, Sage.

De Beauvoir, S. (1997) The Second Sex, translated by H.M. Parshley, London, Vintage.

De Beauvoir, S. (1984) Adieux: A Farewell to Sartre, translated by Patrick O’Brian, London, Andre Deutsch and Weidenfeld \& Nicolson.

Ely, R. (1991) 'Gender differences: What difference does it make?', Academy of Management Best Paper Proceedings, 363-367.

Fingarette, H. (2000) Self-deception, Berkeley, University of California Press.

Gastil, J. (1994) 'A definition and illustration of democratic leadership', Human Relations, 47(8), 953-957.

Hojgaard, L. (2002) 'Tracing Differentiation in Gendered Leadership: An Analysis of Differences in Gender Composition in Top Management in Business, Politics and the Civil Service’, Gender, Work and Organization, 9(1), 15-38.

Laing, R.D. (1990) The Divided Self: An Existential Study in Sanity and Madness, Harmondsworth, Penguin. 
Lawler, J. (2005) 'The Essence of Leadership? Existentialism and Leadership', Leadership, Vol 1(2), 215-231.

Lewin, K., Lippit, R. \& White, R. (1939) 'Patterns of aggressive behavior in experimentally created “social climates”, Journal of Social Psychology, 10, 271-279.

McClelland (1961) The Achieving Society, New York, Irvington Publishers.

Mahon, J. (1997) Existentialism, Feminism and Simone de Beauvoir, Basingstoke, Macmillan.

Marshall, J. (1995) Women Managers Moving On: Exploring Career and Life Choices, London, Routledge.

Merleau-Ponty, M. (2001) Phenomenology of Perception, translated by Colin Smith, London, Routledge,

Murdoch, I. (1999) Sartre: Romantic Rationalist, London, Vintage.

Myerson, G, (2000) 101Key Ideas: Existentialism, London, Hodder \& Stoughton.

Oakley, J. (2000) 'Gender-based Barriers to Senior Management Positions: Understanding the Scarcity of Female CEOs', Journal of Business Ethics, 27, 321334. 
Powell, G.N., Butterfield, D.A. \& Parent, J.D. (2002) 'Gender and Managerial Stereotypes: Have the Times Changed?', 28(2), 177-193.

Rockmore, T. (1995) Heidegger and French Philosophy: Humanism, Antihumanism and Being, London, Routledge.

Sartre, J-P. (1996a) A Sketch for a Theory of the Emotions, translated by Philip Mairet, London, Routledge.

Sartre, J-P. (1996b) Being and Nothingness, translated by Hazel Barnes, London, Routledge.

Sartre, J-P. (1996c) Hope Now: The 1980 Interviews, translated by Adrian van den Hoven, Chicago, University of Chicago Press,

Sartre, J-P. (1995) Anti-Semite and Jew, translated by George J. Becker, New York, Schocken Books.

Sartre, J-P. (1983) Notebooks for an Ethics, translated by David Pellauer, Chicago, Chicago University Press.

Sartre, J-P. (1982a) Critique of Dialectical Reason (volume I), translated by Alan Sheridan-Smith, London, Vergo. 
Sartre, J-P. (1982b) In Camera and Other Plays, Harmondsworth, Penguin.

Sartre, J-P. (1975) The Wall (Intimacy) and Other Stories, translated by Lloyd Alexander, New York, New Directions Publishing.

Sartre, J-P. (1968) Search for a Method, translated by Hazel Barnes, New York, Vintage Books.

Sartre, J-P. (1966) Existentialism and Humanism, translated by Philip Mairet, London, Methuen.

Sartre, J-P, (1965) Nausea, translated by Robert Baldick, Harmondsworth, Penguin.

Shackleton, V. (1995) Business Leadership, London, Routledge.

Thody, P. (1992) Jean-Paul Sartre, Basingstoke, Macmillan Modern Novelists.

Thody, P. \& Read, H. (2003) Introducing Sartre, Cambridge, Icon Books.

Warnock, M. (1965) The Philosophy of Sartre, London, Hutchinson.

Yukl, G.A. (2002) Leadership in Organizations, London, Prentice-Hall, $5^{\text {th }}$ edition. 


\section{Note}

${ }^{\text {i }}$ The term 'look' or 'gaze' is not used literally - as in seeing - though admittedly that is generally how we first apprehend other people. Rather, it is used to signify how we apprehend things in our consciousness, so, for instance, the process might include other sensory perceptions or even use of the imagination. 